\title{
Hematological Malignancies: Analysis of Myelogram Results over 21 Years in Lome Teaching Hospitals
}

\author{
Irenee Messanh Kueviakoe ${ }^{1,2,3}$, Essohana Padaro ${ }^{1,2}$, Kossi Agbetiafa ${ }^{1,2}$, Yao Layibo ${ }^{2}$, \\ Malewe Kolou $^{1,2}$, Ahoefa Vovor ${ }^{1,3}$, Akuete Yvon Segbena ${ }^{1,2}$ \\ ${ }^{1}$ Faculty of Health Sciences, University of Lome, Lome, Togo \\ ${ }^{2}$ Hematology Laboratory of Campus Teaching Hospital of Lome, Lome, Togo \\ ${ }^{3}$ Hematology Laboratory of Sylvanus Olympio Teaching Hospital of Lome, Lome, Togo
}

Email address:

kueviam@hotmail.com (Irenee. M. Kueviakoe)

\section{To cite this article:}

Irenee Messanh Kueviakoe, Essohana Padaro, Kossi Agbetiafa, Yao Layibo, Malewè Kolou, Ahoefa Vovor, Akuete Segbena. Hematological Malignancies: Analysis of Myelogram Results over 21 Years in Lome Teaching Hospitals. Clinical Medicine Research.

Vol. 4, No. 4, 2015, pp. 111-115. doi: 10.11648/j.cmr.20150404.14

\begin{abstract}
Objectives: Determine the frequency of malignancies diagnosed in myelogram seen in hematology services of Campus and Sylvanus Olympio Teaching Hospitals in Lome from 1992 to 2013. Study the epidemiology profile of these diseases. Materials and methods: It was an analytical retrospective study of 469 cases of malignancies diagnosed in 1511 myelograms during 21 years in both teaching hospital of Lome. Results: Blood disorders represent $31.70 \%$ of the results of myelogram performed during 21 years in the Teaching Hospital of Lome. Each year, there is an average of 22.3 cases diagnosed hematological malignancies. The most hematological malignancies were Kahler's disease (28.57\%), chronic myeloid leukemia (24.52\%), chronic lymphocytic leukemia (22.17\%), acute lymphoblastic leukemia (12.58\%) and acute myeloid leukemia $(8.10 \%)$. Other $(4.05 \%)$ were represented by the essential hypereosinophilic syndrome (4 cases), hairy cell leukemia (4 cases), Sezary lymphoma (3 cases), essential thrombocythemia (3 cases), Waldenstrom's disease ( 2 cases), acute myelomonocytic leukemia ( 1 case), prolymphocytic leukemia ( 1 case) and plasma cell leukemia ( 1 case). By gender, the CLL is most predominant in women against CML in men. Hemopathies were observed at all ages of life. Conclusion: Hematological malignancies are diagnosed in the Teaching Hospital of Campus and Sylvanus Olympio in Lome with a high relatively frequency. This prevalence must be higher if all cases of malignancies diagnosed in Togo were recorded in a national cancer register. This study aims to knowledge of epidemiological aspects of hematological malignancies and improve the care of patients with hematological malignancies by the provision of adequate anti-mitotic drugs.
\end{abstract}

Keywords: Hematological Malignancies, Frequency, Epidemiology, Togo

\section{Introduction}

Hematological malignancies are conditions results from abnormal proliferation of hematopoietic cells. They are classified according to the proliferative nature and type of cells into two groups:

- Acute hematologic malignancies: acute lymphoblastic leukemia (ALL) and acute myeloid leukemia (AML)

- Chronic hematological malignancies: myeloproliferative disorder (chronic myeloid leukemia (CML), polycythemia vera or primary polycythemia, myelofibrosis or primary myelofibrosis, essential thrombocythemia) and lympho proliferative syndrome (chronic lymphocytic leukemia (CLL), hairy cell leukemia, multiple myeloma bone disease or Kahler disease).

Several studies of hematologic malignancies were done by different teams in the world about the epidemiological study, the path o physiological study to explain the signs of the disease and lead to precise and specifie treatment [1][2].

With the supply difficulties of anticancer drugs that cost expensive in our country, it would be wise to have reliable data to guide health authorities to make available to the basics antimitotic drugs.

This study aimed to determine the frequency of different malignancies based on age and gender, to precise the 
arguments for the provision of different antimitotic management protocols in public hospitals of Lome.

\section{Materials and Methods}

It was an analytical retrospective study from january 1992 to december 2013 (21 years) in the Hematology Services of the two teaching hospitals in Lome (Campus and Sylvanus Olympio).

The registers of myelogram results were used. Were taken into account, date, age and sex of the patients and the result of the myelogram.

All myelograms during the period of study were included. The myelograms are only realized by hematologists in Lome. The myelograms only failed to make any diagnosis; it took more tests in order to establish the diagnosis from the suspicion contained in bone marrow aspiration. Thus the results presented from the bone marrow aspiration to be exact benefited from the support of cytogenetic analysis, immunochemical studies and flow cytometry.

\section{Results}

Over 21 years, 1511 myelograms have been made and 469 cases diagnosed hematological malignancies (i.e. $31.70 \%$ of cases) with an annual incidence of 22.30 cases per year. Acute hematologic malignancies represented $20.68 \%$ of cases, against $79.32 \%$ for chronic. These blood diseases were observed in subjects from 1 to 82 years with $51.17 \%$ of male subjects for $48.83 \%$ female (sex ratio: 1.05 ).

Per year, the number of malignancies diagnosed myelogram is shown in Figure 1.

The most diagnosed malignancies were Kahler's disease, chronic lymphocytic leukemia, chronic myeloid leukemia, acute lymphoblastic leukemia and myeloid and (Figure 2). Other malignancies found $(4.05 \%$ of total) were represented by the essential hypereosinophilic syndrome (4 cases), hairy cell leukemia (4 cases), Sezary's lymphoma (3 cases), essential thrombocythemia (3 cases), Waldenstrom's disease (2 cases), acute myelomonocytic leukemia (1 case), prolymphocyte's leukemia (1 case) and plasma cell leukemia (1 case).

Figure 3 listed the different types of blood diseases observed by gender.

The age of patients with hematologic malignancies ranged from 1 to 85 years (Figure 4).

The average age for acute was 25.45 years, ranging from 1 to 73 years and the chronics of 52.56 years, ranging from 1 to 85 years.

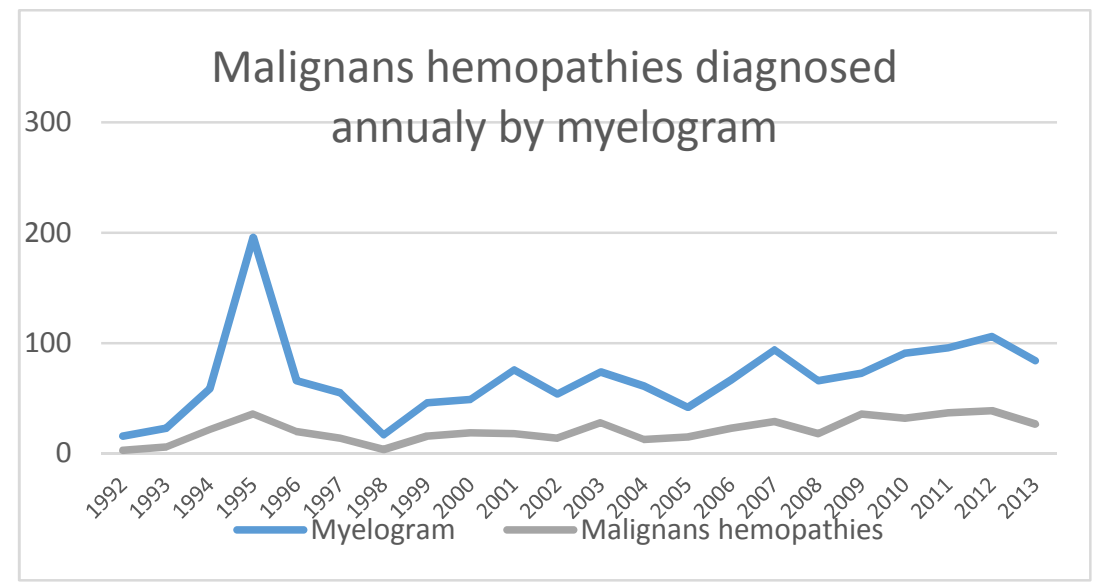

Figure 1. Malignans hemopathies diagnosed annualy by myelogram.

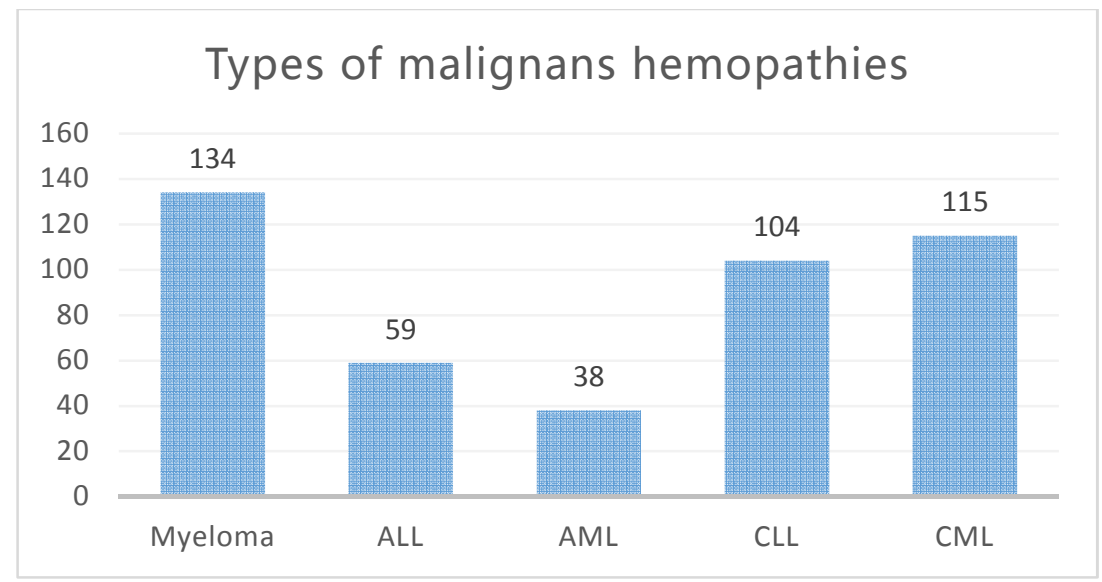

Figure 2. Types of malignans hemopathies diagnosed by myelogram. 


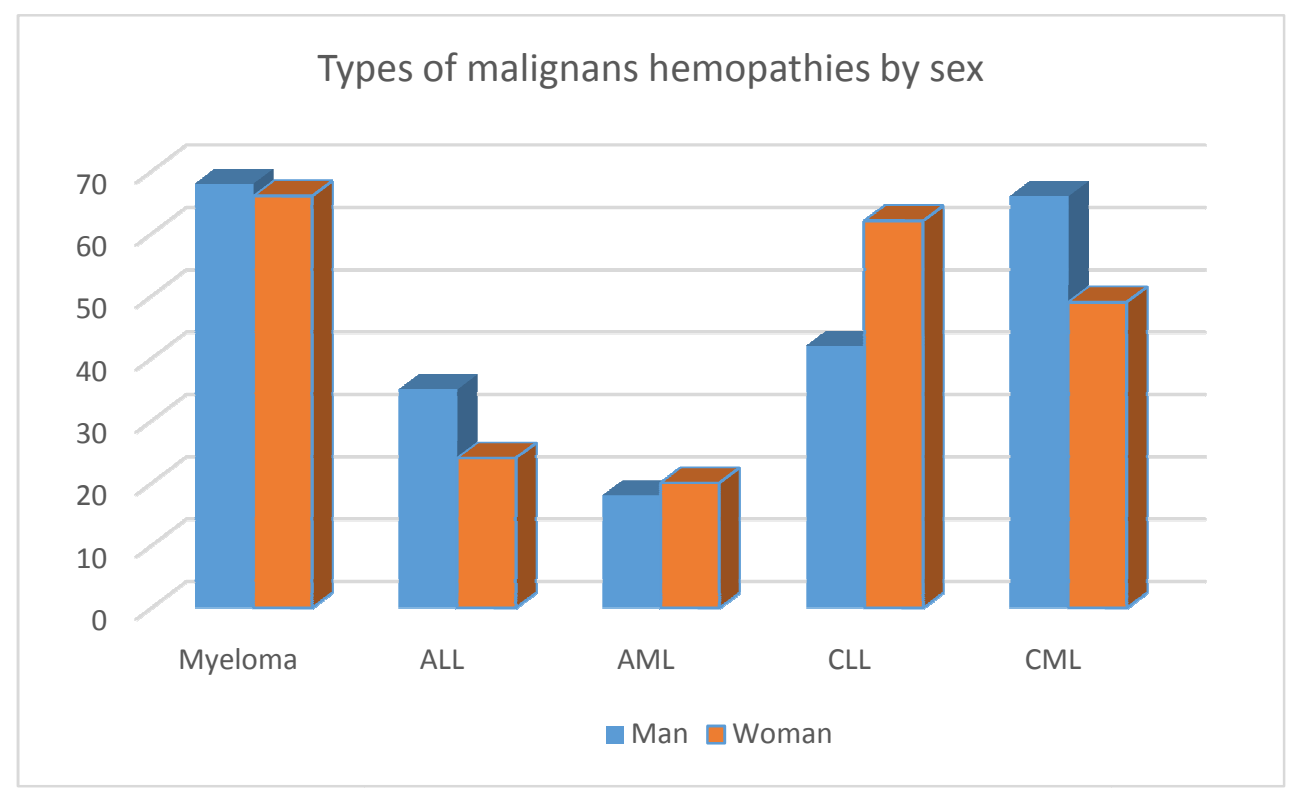

Figure 3. Types of malignans hemopathies diagnosed by myelogram by sex.

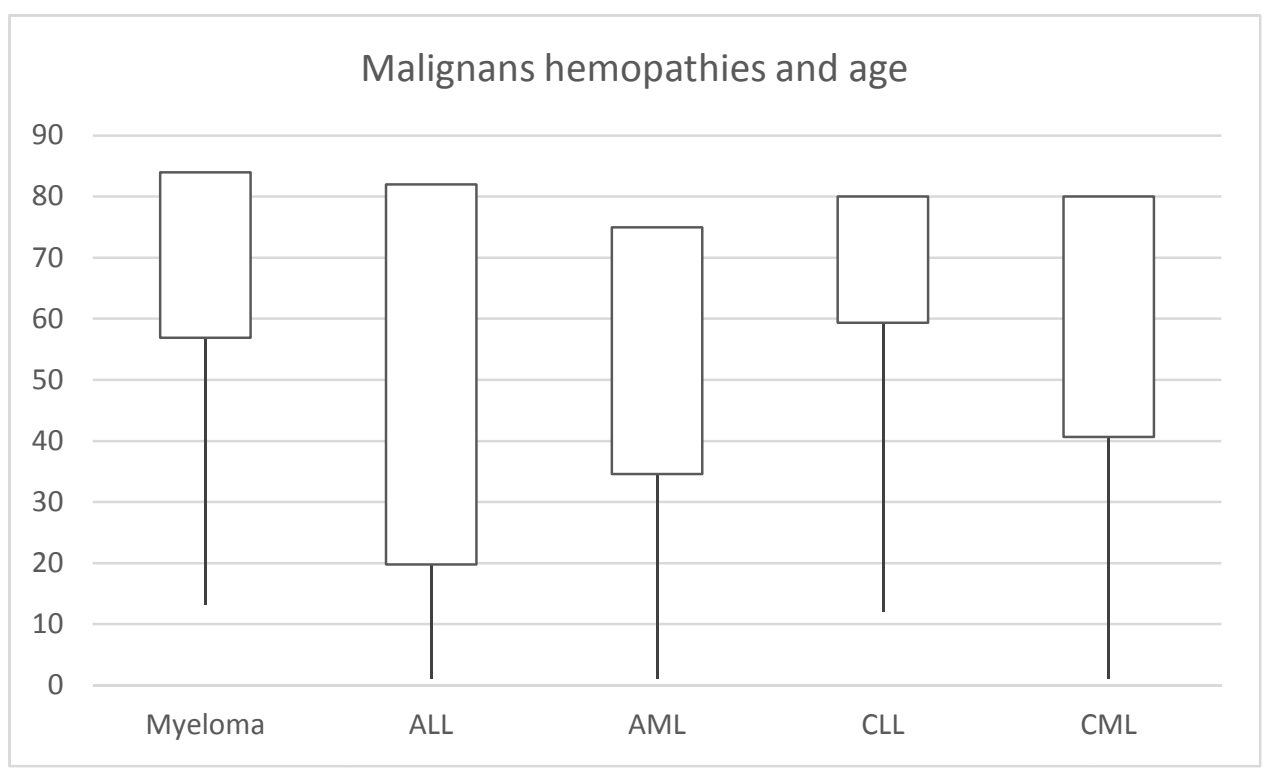

Figure 4. Types of malignans hemopathies diagnosed by myelogram by age.

For rare hematological malignancies observed, the patient's age at diagnosis was 38 years for plasma cell leukemia, 67 for prolymphocyte's leukemia, 15 years for acute myelomonocytic leukemia, 52 to 68 years for the Sezary's disease, 42-82 years for the essential hypereosinophilic syndrome, 54 to 70 years for essential thrombocythemia, 43 to 65 for hairy cell leukemia and 48 to 70 years for Waldentröm's disease.

\section{Discussion}

Over 21 years, $31.70 \%$ of malignancies were identified, with a hospitable annual frequency of 22.30 cases.

Most studies in Africa and the world focused on hematological malignancies in their specificity ie pathologies taken individually.
Our results are well above those of Lokrou in Cote d'Ivoire [3] who found an annual incidence of 13.83 cases. We have used other tests to establish the diagnosis, which may explain the difference observed, as the studies were not made during the same period.

Hematological malignancies appear to be more common in developed countries this because paraclinical assessments are made to a health problem and diagnosis easier. While in our countries due to lack of insurance coverage mainly to lack of technical facilities and the scarcity of hematological consultations, many diseases are not diagnosed.

Blood disorders were diagnosed in our subjects between 1 and 82 years with almost the same frequency in patients male and female sex. This will mean that blood diseases may be encountered at any age and regardless of sex.

The hematological frequency encountered increased 
because of the more number of specialists in hematology during the time.

For a better analysis of the results, we will take the most frequently found hematologic, then we will develop one by one, and so we will group the rare blood diseases in our context.

\subsection{Kahler's Disease (Bone Multiple Myeloma)}

With 134 cases diagnosed in myelogram in the two teaching hospitals of Lome, multiple myeloma represented $28.57 \%$ of pathologies and $8.86 \%$ of all myelogram realized. Studies in Côte d'Ivoire by Toutou [4] and Segbena [5], noted a respective annual prevalence of 2.18 cases and 2.4 cases. If we extrapolate, we find fewer cases than them. The change in frequency in different studies in developing countries noted the difficulty of epidemiological studies of disease. Regarding hematological, the existence of a cancer register could facilitate the task.

There are in our study as many men than women, while a male predominancy was found by Koffi [6] (1.3) Toutou [4] (2.42) and Segbena [5].

In 1992 Marie and al [7] found that in France there is no predominance of one sex over the other. These results are similar to ours.

The average age was $56.86 \pm 13.11$ years with extremes of 23 and 84 years. These results were not similar to those of several authors Marie [7] in France (average age between 60 and 65 years), Segbena [5] and Koffi [6] in Cote d'Ivoire (mean age respectively 58.5, 58 and 58 years). It seen that our populations of Kahler's disease were younger than in occident country.

\subsection{Chronic Myeloid Leukemia (CML)}

CML was diagnosed in 115 cases, or $24.52 \%$ of hematological malignancies found and $7.61 \%$ of myelogram realized and thus ranks third blood diseases diagnosed in our services. These results are similar to those in Togo Atinoto [8] with 25.8;

Male dominance in our series (sex ratio: 1.35) was also found in the literature: 1.5 to 1.77 Guihot in USA [9] for Dokekias in Congo [10]; and 7 for Lokrou [3] in Côte d'Ivoire. Zittoun in France [11] found a sex ratio of 1.5 before 30 years.

The average age was $40.65 \pm 16.29$ years, with a range of 1 to 80 years. Dokekias [10] in 1999 in Congo found an average age of 33.28 years. In France, for Zittoun [11] in 1988 and in 1999 Guilhot [9] maximum frequencies were between 40-50 years and 50-60 years. CML is more common in adults from 36 years but the frequency decreases beyond 50 years.

\subsection{Chronic Lymphocytic Leukemia (CLL)}

With 104 cases $(22.17 \%$ of hematological malignancies and $6.88 \%$ of the myelogram realised, the CLL was third. On average 4.95 cases are diagnosed each year. These results are comparable to those of Atinoto [8] which had found 4.38 cases per year in Togo in 1998 and Yao [12] in 1991 in Cote d'Ivoire with an annual prevalence of 5.75 cases. Yao [12] in 1981 and Segbena [5] in 1991 respectively felt this annual prevalence 6.27 and 6 cases. Relatively high rates have been reported in Côte d'Ivoire by Tea [13] 8.25 and in France by Carli [14] 26.5 cases. This difference could be explained by the cases recruited. The technical platform is more developed in advanced countries.

A female predominance was found (sex ratio 0.68). This female predominance was found respectively in Cote d'Ivoire by Lokrou [3], Yao [12] and Segbena [5] and in Togo by Atinoto [8] with $0.8 ; 0.8 ; 0.5$ and 0.66 . In contrast in France, Carli [14] and Dighiero [15], had found a male predominance respectively with 3.1 and 1.8 in their studies. Would there be a feature in the black patient in the occurrence of CLL?

The average age was $59.35 \pm 12$ years, ranging from 17 to 80 years. These results were similar to those found in Côte d'Ivoire and Togo by Segbena [5] and Atinoto [8] respectively 56.53 and 59 . They are against higher than Yao [12], Tea [13] in Cote d'Ivoire whose values were 50 and 52 years respectively. For Dighiero [15], CLL was exceptional before 30 years and was observed in France after 50 years with a peak incidence around 60 years.

Yao [12] and Segbena [5] in Ivory Coast, respectively observed maximum frequency between 41-50 years and 5560 years. Carli in France [14] said the CLL did not exist before 25 years and was rare before 50 years and the frequency increased from 50 years.

These results reflect the observations reported in the literature. For Desablens [16], the CLL was predominant in Africa in young adults while elsewhere (Europe and North America) is a disease of elderly (60 years). This affirmation of Desablens [16] was in total contradiction with our study and that of other african authors $[5,10,13]$. The CLL is also common in the elderly in Africa.

\subsection{The Acute leukemia (LA)}

Acute leukemias in fourth place with 97 cases or $20.68 \%$ of malignancies diagnosed myelogram over 21 years $(4.61$ cases per year). This estimate is similar to that of Atinoto [8] in Togo who had found four cases per year. According Vernant [17], the frequency of acute leukemia was 3 cases / 100000 inhabitants by year in Western countries. For Dokekias in Congo [18], the prevalence of blood disorders was 9.6 cases. This large discrepancy could be explained by education of the population know that we had to go to hospital in case of illness for an accurate diagnosis and proper treatment. Also that practitioners should understand that it takes a good exploration of the patient for a proper diagnosis.

The sex ratio of acute leukemia in our series was 1.2. It was 0.8 in Congo according Dokekias [18]. Male or female vary by region.

Acute lymphoblastic leukemia were observed in 59 subjects and myeloid in 38 subjects. The difference by 
gender is not statistically significant.

\subsection{Other Hematological Encountered}

In order of frequency are found the essential hypereosinophilic syndrome with FIPIL1-PDGFRA confirmation in molecular biology, Sezary's syndrome, essential thrombocythemia, Tricholeucocyte leukemia, Waldenström's macroglobulinemia with IgM, Plasma cell leukemia (AgCD36) and prolymphocytics leukemia. It is obvious that these conditions appear to be rare because of the diagnosis only mentioned and confirmed by specialists. This would mean that if these conditions are commonly sought, frequency will highly. In developed countries, the diagnosis is easy with the technical tools developed; while in our country, their confirmation is still a problem because of the limitation of the technical bids.

\section{Conclusion}

Hematological malignancies are conditions resulting from the uncontrolled proliferation of blood abnormal cells.

In the teaching hospitals in Lome, the most experienced chronic blood diseases are those (Kahler's disease, chronic myeloid leukemia and chronic lymphocytic leukemia); then acute leukemia due to their poor prognosis from the outset (the diagnosis cannot be done early because of the long delay of consultation in our country). Our population have not culture of medical visits without disease and not understand or refuse the long term follow up (case of lost contact with patient).

This study shows the frequency of hematological malignancies encountered in Togo available to health authorities and allow them to choose antimitotic drugs to be included on the list of essential drugs in the country.

\section{References}

[1] Mahon F-X. Leucémie myéloïde chronique et inhibition de la tyrosine kinase. Rev Med Interne 2001; 22: 894-9

[2] Bories D. Physiopathologie moléculaire de la leucémie myéloïde chronique. Hématologie 2001;7:6-12.

[3] Lokrou A, Toutou T, Diallo A, Groga-Bada, Ouedraogo Y, Koutouan A, Tea N, Niamkey E, Soubeyrand J, Beda Y. Leucose et Lymphomes dans un service de Médecine Interne à Abidjan. Med; Afr. Noire, 1988, 35 (4), 305-310.

[4] Toutou T. Contribution à l'étude du myélome multiple en milieu africain. A propos de 24 cas dont 22 autochtones. Thèse : Méd : Abidjan : $1981 ; 313$.
[5] Segbena A.Y. Contribution à l'étude des hémopathies lymphoïdes malignes chez le Noir Africain. Thèse : Abidjan : 1991, 1261.

[6] Koffi K.G, Sanogo I, Trazo D, Toure A.H, Tolo A, N'Guessan K, Danho N.C, Kouakou N, Sangare A. Caractéristiques du myélome multiple du noir africain. Expérience de la Côte d'Ivoire, Méd. Afr. Noire, 2000, vol. 47, n 10 , pp. 430 - 435.

[7] Marie J.P, Delmer A, Herait P. Hématologie pratique ImpactInternat 1992,139-203

[8] Atinoto K. Profil clinique, biologique et thérapeutique de la leucémie lymphoïde chronique dans les CHU de Lomé. Mém Ass Med : Lomé 2000 ; pp 25-47.

[9] Guihot F. Chronic myeloid leukaemia. Textbook of malignant haematology (1999).

[10] Dokekias E.A, Malanda F. La leucémie myéloïde chronique quel avenir thérapeutique en Afrique noire ? Revue : Tunisie médicale. [Tunis. méd.] , 2003, vol. 81, no 3, pp. 172 - 179

[11] Zittoun R, Samama M, Marie J.P. Leucémies et états apparentés In : Manuel d'Hématologie Paris : Doin : 1988 ; $397-427$.

[12] Yao T, Tea D.N, Rain J.D. Leucémie lymphoïde chronique en Côte d'Ivoire. Méd. Trop. 51,4, oct.-déc. 1991, 417-420.

[13] Tea D, Yao T, Rain J D. Aspects particuliers de la leucémie lymphoïde chronique (L.L.C.) en Côte d'Ivoire Rev. Méd. Côte d'Ivoire, 1982, 16, (57), 37-40.

[14] Carli P M, Milan C, Bordes M, Bonhomme J. Etude de l'incidence de la leucémie lymphoïde chronique dans le département de la Côte d'Or. Nouv. Rev. Fr. hémato, 1986, 28, 23-26.

[15] Dighiero G, Travade P, Chevret S, Fenaux P, Chastang C, Binet J L. The French Cooperative Group on CLL: B-cell chronic lymphocytic leukaemia. Present status and future direction. Blood 1991; 78: 1901.

[16] Desablens B. Leucémie lymphoïde chronique. Diagnostic, évolution et pronostic. Rev. Prat. (Paris), 1990, 40, (23), 21952198.

[17] Vernant J.P, Brun B. Leucémies aiguës. In : Hématologie Paris : Flammarion : 1986 ; pp. 471-504.

[18] Dokekias E.A, Bidzouta-Matingou P, Malanda F, Ntsihou D, Nzingoula S, SANOGO L. Configuration épidémiologique et cytologique des leucémies aiguës au Centre Hospitalier et Universitaire de Brazzaville, Revue : Tunisie médicale. [Tunis. méd.], 2004, vol. 82, no 11, pp. $1019-1025$. 